\title{
Editorial Role of a Clinical Biochemist in Evaluating the Impact of Lead Poisoning
}

\author{
Thuppil Venkatesh
}

Published online: 21 December 2012

(C) Association of Clinical Biochemists of India 2012

World Health Organization has declared that one of the toxic heavy metal "Lead" as number one environmental hazard all over the world with over 120 million people is overexposed to lead and 99 percent of the most serious cases are in the developing world. Lead and its various salts have a significant role in environment and has impact on health which is of great concern and is a multidisciplinary topic of great concern. Understanding of the toxic effects of lead over the past 30 years is an outstanding example of how knowledge generated from simple research can impact public health. Efforts by scientific community have made the greatest impact on reducing exposure to lead, are reduction of lead from gasoline by the efforts of The George Foundation Project Lead Free in the year 2000 in India, elimination of lead solder from canned food, removal of lead from paint in 2011, and abatement of lead-based paint as an ongoing effort in most of the developing countries.

While Lead toxicity is a grave problem in environmental pathology [1], Biochemists have looked into the effect of lead on various biochemical pathways. With this clinical lead poisoning was understood in greater detail. The most important signs and symptoms of overt lead intoxication were confined to central nervous system, haemopoitic system and the renal system. Children with acute lead poisoning present clinically with ataxia or even with convulsions or even a reduced level of consciousness [2] Adults rarely have such CNS symptoms unless there is

T. Venkatesh $(\square)$

Professor Emeritus Department of Biochemistry and Biophysics, Quality Council of India, National Referral Centre for Lead

Projects in India (NRCLPI), St John's Medical College,

Bangalore 560034, India

e-mail: venkatesh.thuppil@gmail.com massive exposure to lead vapors or organic forms of lead in illicit alcohol drinks [3]. Whether it is the competition of lead with calcium in various biochemical mechanisms or the direct effect of lead on the active sites of enzymes lead seems to have many deleterious effects in a biological system.

Orfila in 1817 made a statement which is of great concern even today. The statement is "If we were to judge of the interest excited by any medical subject by the number of writings to which it has given birth we could not but regard the poisoning by lead as the most important to be known of all those that have been treated of, up to the present time." This information was arrived by going through Parrish, Case of Suicide in a Child. [4].

Biochemists have diagnosed, evaluated, and helped in the treatment of lead poisoning in general population [5], Elevated blood lead levels and cytogenetic markers in painters exposed to lead containing paints indicated another major source of lead [6] With reference to occupational exposure to lead and subsequent elevated blood lead levels, evaluation and treatment of wrist drop in a patient due to lead poisoning was studies by biochemists [7] Another major breakthrough considering paints as the major source of lead author was involved in multi country study in evaluating the impact of lead from lead based paints [8.] Lead and genotoxicity study used blood lead levels and its correlation to other cytogenetic markers (Elevated blood lead levels and cytogenetic markers in buccal epithelial cells of painters in India [6].

India being the major source of ayurvedic medicines had to face major problem when scientific papers did demonstrate the presence of high levels of lead and other toxic heavy metals in the ayurvedic preparations sold on internet in USA [9, 10]. Many similar studies in India did reveal 
lead poisoning caused by the use of unbranded ayurvedic medicines [11].

Studies undertaken by the team of clinical biochemists in India at the National referral Centre for lead Projects in India (NRCLPI) located at Bangalore since 1996 resulted in getting unleaded gasoline in India in March 2000. Following this abatement of lead in paints were successfully achieved in the year 2011. New governmental policies were emerged at AYUSH to safeguard our traditional medicines. Cost of blood lead level was brought down from 1,800 to mere 500 Rs with better technology and a turnaround time of less than 15 min after drawing blood and the quantity of blood requirement was brought down to $50 \mu \mathrm{L}$. When no uniform methodologies were adopted for the blood lead evaluation biochemists made an effort to introduce the DP ASV point of care with lead care system. Sixteen centers across the country have now lead clinics with same uniform technology to evaluate blood lead levels apart from providing the much needed guidance to the treating clinicians. Plans are made to establish 100 lead clinics across the country by the end of 2013 . Over 15,000 school teachers and NGO's are trained in the basics of lead poisoning and its prevention by the team of biochemists in India.

\section{References}

1. Goyer RA. Lead toxicity. Am J Pathol. 1971;64(1):167-82.

2. Benson P. Lead poisoning in children. Dev Med Child Neurol. 1965;7:569-71.

3. Morris CE, Heyman A, Pozefsky T. Lead encephalopathy caused by the illicitly distilled whiskey. Neurology. 1963;14:493-9.

4. Orfila. Am J Med Sci. 1837; 21:258-259.

5. D'souza HS, Dsouza SA, Venkatesh T. Diagnosis, evaluation, and treatment of lead poisoning in general population. Indian $\mathbf{J}$ Clin Biochem. 2011;26(2):197-201.

6. Khan MI, Ahmad I, Venkatesh T. Elevated blood lead levels and cytogenetic markers in buccal epithelial cells of painters in India: genotoxicity in painters exposed to lead containing paints. Environ Sci Pollut Res Int. 2010;17(7):1347-54.

7. Dsouza HS, Dsouza SA, Thuppil V. Evaluation and treatment of wrist drop in a patient due to lead poisoning. Ind Health. 2009;47(6):677-80.

8. Scott C, Clark CS, Krishna G, Rampal KG, Yu J. Lead levels in new enamel household paints from Asia, Africa and South America. Environ Res. 2009;109(7):7.

9. Saper RB, Kales SN, Thuppil V. Metal content in ayurvedic medicines. JAMA. 2009;301(3):272-272.

10. Stefanos N, Kales SN. Lead, mercury, and arsenic in US- and Indian-manufactured ayurvedic medicines sold via the Internet. JAMA. 2008;300(8):915-23.

11. Geraldine M, Herman DS, Venkatesh T. Lead poisoning as a result of infertility treatment using herbal remedies. Arch Gynecol Obstet. 2007;275(4):279-81. 